\title{
Assessing the Employee Value of IT Staff via Employee Value Equation Variables from the Value Profit Chain Framework
}

\author{
Nora Shafinaz Saedun ${ }^{\# 1}$, Ibrahim Mohamed ${ }^{\# 2}$

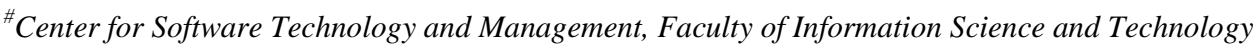 \\ Universiti Kebangsaan Malaysia, 43600, Bangi, Selangor, Malaysia \\ E-mail: ${ }^{1}$ mizphinaz@gmail.com, ${ }^{2}$ ibrahim@ukm.edu.my
}

\begin{abstract}
Nowadays, company competencies are significantly improving as a result of Information Technology (IT), which also acts as a support and leading player in businesses. IT employees are accredited as a crucial resource, but they are not given as much care as other IT assets. The minimal attention given in retaining professional and worthy employees may result in their leaving their profession. This may impact business performance, as company performance and quality that employees deliver to the customers are also affected. This research was conducted to explore the tools for measuring IT employee value within a company. From a review of past studies, the Value Profit Chain (VPC) framework was found to propose a method to estimate the value of an employee in a model known as the Employee Value Equation. Although this is a good method for measuring employee value, only the theoretical aspect of employee value is defined, so further investigation is required to support this equation.
\end{abstract}

Keywords—retaining employees; IT employees; satisfaction; employee value; value profit chain; turnover.

\section{INTRODUCTION}

Company IT assets may consist of tangible or intangible assets such as information, or system or hardware used in the course of business activities. Employees are defined as essential resources [1] in the IT field, as they are the primary users of information, but they are given less attention compared to other IT assets [2]-[4]. IT sector employees are facing high emotional exhaustion because of their job, long working hours, excessive work pressure, lack of job autonomy in the workplace, and inequity in organizational justice, which lead to a low level of commitment towards their job [5], and finally they are deciding to quit.

According to Manpower Group in a $10^{\text {th }}$ Annual Shortage Survey, the IT sector is the $5^{\text {th }}$ hardest job to fill in the Asia Pacific when it comes to employee shortage issues [6]. The expertise, familiarity, and ability of highly skilled staff bring profit to the company. Valuable staff are key performers in the company [3] and are therefore crucial to the company's success [7].

However, the rate of IT staff leaving their jobs has spiked in recent years. In one report [8], an increase in IT staff turnover was recorded from $76 \%$ in 1998 to $98 \%$ in 1999 [9]. The highest turnover in the IT sector was observed in Malaysia between 2011 to 2012 [10]-[12].

There is a high turnover of IT staff, and this poses a problem for companies, as the current objective of IT is to help the organization. Therefore, staff turnover is known as a liability to the company, especially in the IT industry [13]. IT investment is intangible and should be looked at from a different view, which requires separate exploration [14]. This may impact the internal atmosphere including employee turnover. Labor turnover is a potential threat to knowledge loss [15] and so much more. The crucial issue for IT businesses is not to search for new employees but to keep skilled staff in the company [16]. The real cost of losing employees, which impact the organization, are costs that may be incurred from advertising for new hires, cost of new recruitment, loss of productivity and engagement, training, and cultural impact within the organization [17]. Economy wise, companies are more concerned with keeping competent workers for a more extended period [18], which benefits the organization.

An extended study is needed to find suitable ways to keep staff [17] and determine their value to ensure that retaining skilled staff is worth it for the company. From information gathered from a previous study, four factors force staff to leave their jobs, which are the company itself, jobs, salaries, and staff internal factors [19]. Satisfied staff is mirrored by the quality and company performance delivered to the customer. Unsatisfied delivery of service to the customer may lead to a loss in business that may impact company profitability. The primary reason why a company can perform well is that of the output delivered by the skilled staff. Skilled staffs are more effective and productive in 
delivering good services to customers. This is also a sign of success-driven organizations, especially from the viewpoint of stakeholders [20]. The main role-players in a business are the clients, staff, and investors. There are also three critical aspects of ensuring a company secures its place in the industry, which is staff intention to leave jobs, sales, and referrals [21]. Part of the strategic plan for an ICT organization is the identification and categorization of employee capabilities to empower the organization to achieve its business objective [22].

A previous study has revealed several factors for retaining employees but how to calculate employee value is not clearly understood [23]. The problem is not just to retain people but also to retain the right people in the organization [24]. This is why measuring employee value is important; to ensure the organization does not invest in training and developing the wrong person in the company.

This study was prepared according to previous research on turnover among IT staff. Then, employee value theories and how the values can be measured [21] are discussed with the objective [25]-[27] of retaining IT staff in the organization.

\section{MATERIAL AND METHOD}

The design of this research is based on the structured activities in the qualitative and quantitative methods. The detailed flow of research methodology is described in Figure 1 below:

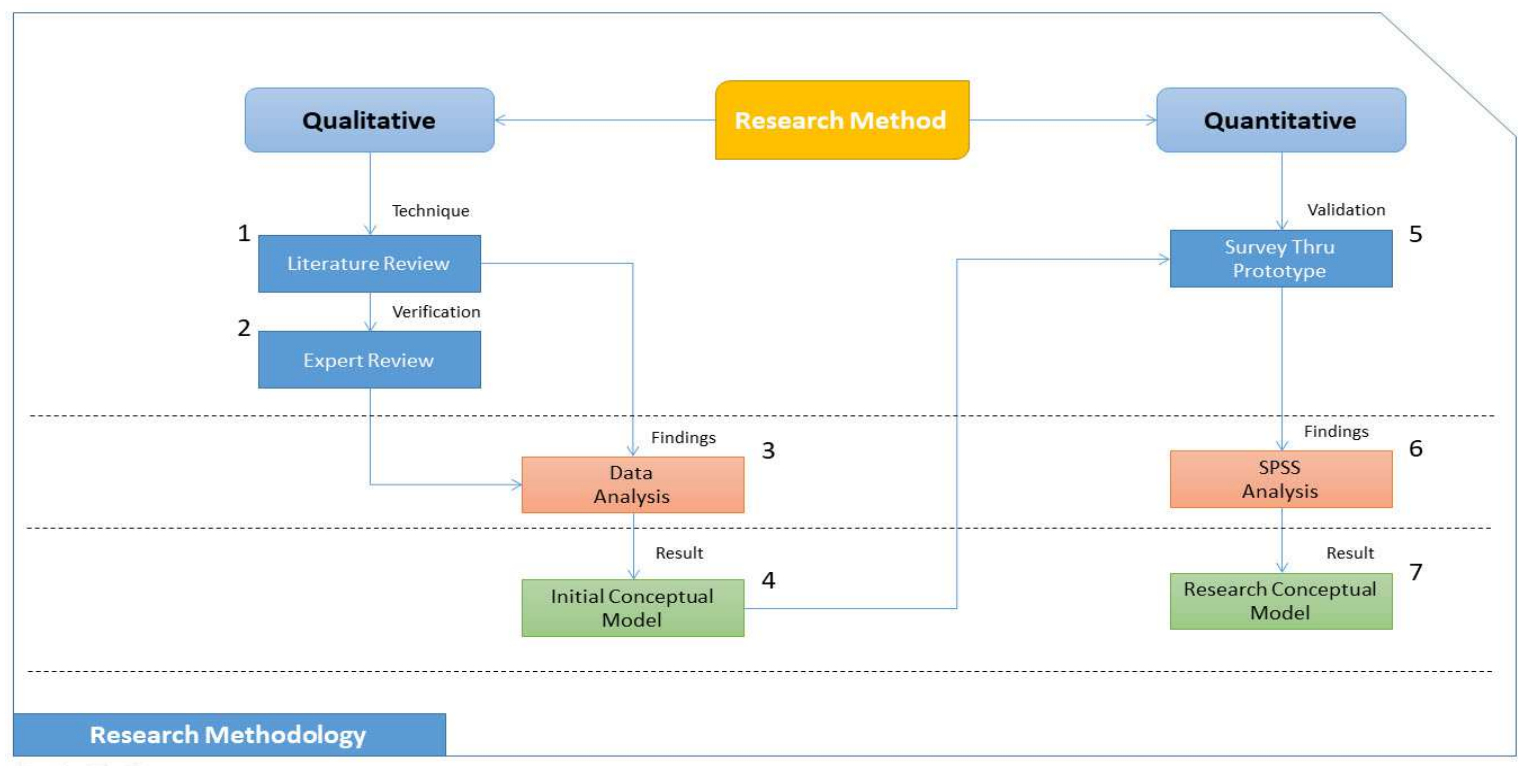

Fig. 1. The Research Methodology

For this study, the research methodology was divided into two phases: the first phase is the verification phase while the second is set aside for validation to meet the objective of whether or not this work was able to measure employee value. For the research methodology of this study, two methods were used, which are the qualitative and quantitative methods.

For the qualitative method in the first phase, initially, the work started with a literature review to define the research question, which is whether or not IT staff value can be measured. This is inclusive of searching for and analyzing the potential framework. The current frameworks are then reviewed by experts from the interview conducted in this study, for verification, and then the most likely to be used in order to measure employee values theoretically was selected. After the theoretical framework is selected, the variables of the framework are analyzed based on the outcomes from the materials gathered. Finally, the initial conceptual model is developed to summarize the result before continuing to the quantitative method to complete the research work.

In the second phase, a questionnaire survey is distributed among the samples in the study. The questionnaire survey is based on the variables of the selected theoretical framework. SPSS is used to validate the data. From the survey data, the initial conceptual model was tested before developing the final research conceptual model.

\section{A. Material - Theoretical Framework}

The essence of this study is to consolidate the findings from models of employee value. The models that define employee value include Employee Value Proposition (EVP), Value Profit Chain (VPC), Retail Value Chain (RVC), and Service Profit Chain (SPC) [28].

In all four models, the employee value is used to explain the worth of the employee based on their job performance. A critical input is the employee value [29], which can assist in creating customer value [20]. Via these good values, the business industry will be positively impacted, and the staff emerges as an important role-player in the company through their skill and experience. In the business operation plan, employee knowledge gives benefit to a company, which interrelates between operation and staffing strategy, resulting in sustainable business significance [20]. Based on a previous study, an organization achieves its mission because of staff that focuses on delivering good services [30].

In 1994, Heskett, Sasser, and Schlesinger established SPC (Service Profit Chain) [31], a model consisting of a set of relationships that are quantifiable and directly linked to 
company revenue, to ensure staff loyalty, output, and satisfaction as well as customer satisfaction and loyalty.

The Service Profit Chain assists service workers to create value at the service point via internal practices. In this way, employees are held accountable for creating customer satisfaction and adding value [8]. Customer loyalty drives SPC progression and revenue. As mentioned in Fig. 2, this framework is based on the ideas that: (1) customer satisfaction is directly correlated with fiscal achievement; (2) employee is directly connected with financial achievement; (3) stakeholders are directly correlated, and (4) employee satisfaction is indirectly correlated with fiscal achievement.

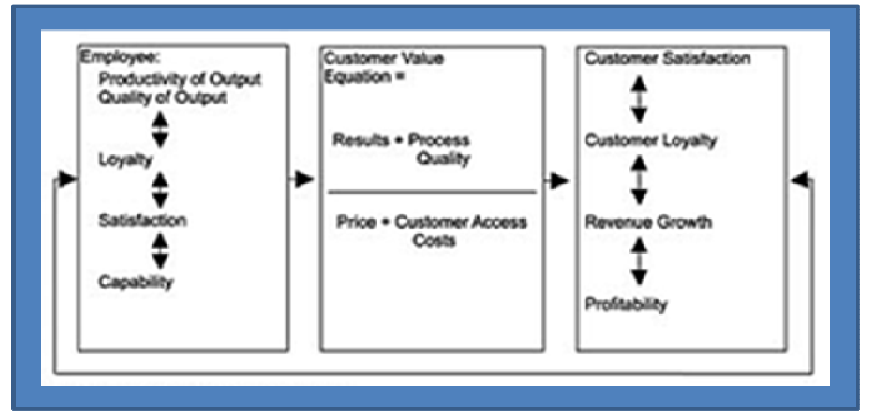

Fig. 2. SPC Model

Although SPC highlights the customer value-employee value relationship, it does not provide an exact calculation for employee values [33]. Furthermore, SPC is targeted towards service sector employees.

Increased retail growth as a result of increased average spending of customers due to changes in staff opinion, leading to increased staff performance, is the main idea behind the Retail Value Chain (RVC) framework. The framework ensures retail sales growth, ascertains the performance and perception of staff, and encourages customer spending [34]. Despite its advantages, RVC only addresses customers in the retail industry.

The balance between employee performance at the office and the rewards and benefits that the employee receives in return are delineated in the Employee Value Proposition (EVP) [25]. The development of a company EVP is based on a combination of organizational procedure, benefits, and characteristics [25] to provide a platform to communicate the employer brand and for knowledge management [27]. Employers stand to attract the best talent and retain top performers with a strong EVP [35]. Nevertheless, EVP is mostly aimed towards attracting employee engagement in the organization in return for recognizing employee contribution [25].

The Value Profit Chain was further developed by Heskett et al. (1994) as a new framework, using SPC as a knowledge base. VPC addresses the weakness of SPC, which only caters to a particular industry, by claiming to cater to more types of industries including the IT sector [21]. The test in this study proves that VPC can indeed be applied in the IT field. VPC focuses on three areas-preservation, correlated trades, and referrals - to describe the effect of productivity and revenue and the connection between employee commitment, fulfillment, and loyalty of customers. The VPC framework is illustrated in Fig. 3, indicating that there is a connection between the mutually supporting elements of employee values, satisfied customers, stakeholders, and reinvested values for partners.

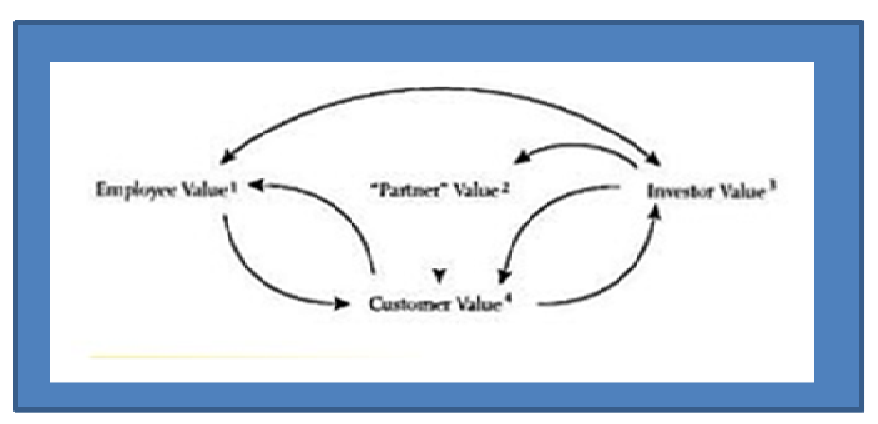

Fig. 3. The Model of VPC

The primary drivers behind successful commerce, according to the VPC concept, are customer fulfillment and loyalty, staff values, and customer values. Employee satisfaction, loyalty, and productivity depend on the values that they carry; hence, an employee that is more active and productive can convey a better quality company to customers [36], [37]. Once employees show good values, this will attract other customer values such as trust, assurance, loyalty, and satisfaction, which will positively impact the business. This is because positive customer values drive organizational growth and profitability, which in turn lead to continued investment from investors. This results in partnership reinvested values, which includes investors, customers, communities, and suppliers. Besides that, any new ideas put forth by the organization will receive backing from devoted investors, which in turn sustain the organization for long.

From analyzing VPC, it can be observed that the VPC framework can be implemented in the IT sector [21], [38]. In the 1970s, Heskett et al. [21], [39] aimed to prove that VPC could be applied in numerous fields by identifying the common attributes of successful companies. They found that firms that are successful have a good record of high employee capability and fulfillment, with a focus on increasing customer loyalty and satisfaction by offering increased customer value. Furthermore, sales growth, revenue growth, or turnover, which are key performance indicators for organizations [21], and their link to employee values such as loyalty, commitment, fulfillment and customer satisfaction, are the keys to proving the success of applying this chain.

Scholars believe that to inculcate other values in an organization [40], the foremost priority should be put on empowering employee values [[21]. More customers can be brought in via talented and satisfied employees, who offer great products or services that meet customer needs. Business performance is, in turn, increased when satisfied customers reward the organization with future referrals or repurchases [41]. The above scenario shows the importance of retaining valuable employees in the organization [21]. In this way, businesses with little turnovers need not invest much in recruiting new employees.

An assessment by experts was conducted, with the results outlined in Table I, to choose a suitable framework for measuring employee value. The assessment is based on a score of 5 for Excellent, 4 for Good, 3 for Neutral, 2 for Poor, 1 for Very Poor, and 0 for Not Applicable. 
TABLE I.

FRAMEWORK SELECTION

\begin{tabular}{|l|l|l|l|l|}
\hline Criteria & RVC & VPC & EVP & SPC \\
\hline $\begin{array}{l}\text { The framework mentions } \\
\text { employee value. }\end{array}$ & 5 & 5 & 5 & 5 \\
\hline $\begin{array}{l}\text { Employee value is measured via } \\
\text { the framework theory. }\end{array}$ & 2 & 5 & 3 & 2 \\
\hline $\begin{array}{l}\text { Supports the theory of employee } \\
\text { value. }\end{array}$ & 5 & 5 & 5 & 5 \\
\hline $\begin{array}{l}\text { Addresses the calculation of } \\
\text { employee value. }\end{array}$ & 1 & 5 & 2 & 2 \\
\hline $\begin{array}{l}\text { A specific equation can be used } \\
\text { to measure employee value. }\end{array}$ & 1 & 5 & 3 & 0 \\
\hline $\begin{array}{l}\text { The objective is to retain the } \\
\text { employee in the organization. }\end{array}$ & 0 & 5 & 5 & 1 \\
\hline $\begin{array}{l}\text { The framework theory suits the } \\
\text { IT industry. }\end{array}$ & 0 & 5 & 0 & 0 \\
\hline $\begin{array}{l}\text { The framework can be used to } \\
\text { measure IT employee value. }\end{array}$ & 3 & 5 & 3 & 3 \\
\hline $\begin{array}{l}\text { Can be implemented for front- } \\
\text { end and back-end employees. }\end{array}$ & 3 & 5 & 4 & 3 \\
\hline $\begin{array}{l}\text { Variables in the equation can be } \\
\text { applied in the IT sector. }\end{array}$ & 0 & 5 & 4 & 0 \\
\hline TOTAL & $\mathbf{2 0}$ & $\mathbf{5 0}$ & $\mathbf{3 4}$ & $\mathbf{2 1}$ \\
\hline
\end{tabular}

This assessment shows that the VPC [21], particularly the theory of employee value, is an apt framework to apply to measure employee value [28]. Furthermore, this framework also offers an equation for employee value measurement. In the VPC framework, the primary objective of the employee value equation is the measurement of the employee value in order to retain competent and valuable employees in the organization.

This equation [21] describes the connection between employee, customer, and partner relationship in creating organizational value. Within the self-reinforcing system, a critical component to creating a long-term partner, investor, and customer value is certainly found in the employee value equation [21]. According to the framework; the more the employee feels included as a part of the company, the more he or she will engage in a team, which could help meet organizational objectives [42], [43] effectively.

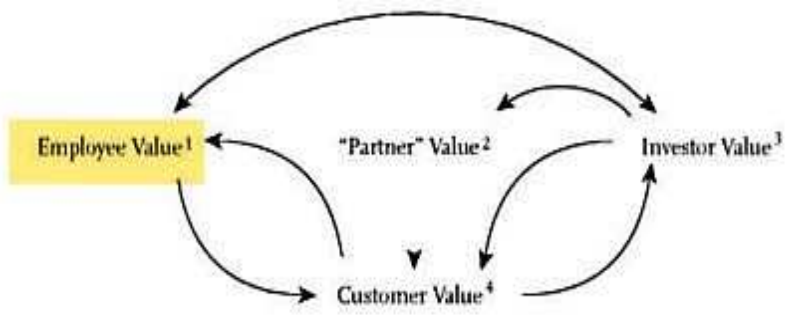

Fig. 4.VPC model

Four variables were identified to support the VPC model. The variables are (1) the ability to convey result; (2) workplace quality; (3) net salary; and (4) job access cost. The ability to convey the result is the variable that determines the competency of employees to submit their work during working hours. The firms can hire ICT-capable persons to facilitate and widen the dynamic competencies within the firm [44]. Workplace quality determines the surroundings where the employee submits their work. The net salary is the wages and remunerations that the employee received. Finally, the job access cost is how much the employee spends in order to reach his company from home [21].

Adapting the equation from the model [21], the investigation continues with an assessment of past research and performing a qualitative method to find suitable variables for the elements. The outcome is then transferred into a conceptual model, which will be the initial concept model serving as the basis before going to the next phase, which is to apply the quantitative method to verify the results.

\section{B. Measuring Employee Value}

The equation below was based on VPC and is used to estimate the value of an employee in an organization. From the Value of Employee equation, $a=$ "Ability to Convey Result," $b=$ "Workplace Quality," $c=$ "Net Salary," while d = "Job Access Cost."

Value of Employee $=$ Ability to Convey Result + Workplace Quality

1/Net Salary + Job "Access Cost."

All variables are elements that support each other in calculating the employee value. Then, the variables are arranged linearly to simplify the process of calculating.

The Equation =

$$
\Sigma \mathrm{n}=(\mathrm{a}+\mathrm{b}) /(1 / \mathrm{c}+\mathrm{d})
$$

For this study, the element " $a$ " was emphasized in order to measure the employee value of IT staff. Related elements were added to the variable " $a$ " to ensure it suits the IT field, while new elements from other variables were also augmented to complete this study. Additional elements to support in delivering results (for " $a$ " variable) are IT capability, commitment, and support by stakeholders, helpful team members, and optimum resources.

\section{Data Collection}

In this study, we used simple random sampling to collect data. The data was collected from 200 staffs in an IT department. The distribution of the samples was segregated into five sections. From 200 staffs, the total target sample was narrowed down to 50 samples with ten staffs from five sections within the department.

Each sample was given a questionnaire survey, which was developed from the elements of the variables in the equation. This study was conducted by distributing the survey questionnaire, which covered four variables describing the equation. All employees were given options to answer, from 1 to 7 for each question, with one indicating Strongly Disagree and seven indicating Strongly Agree.

\section{RESULTS AND DISCUSSION}

To interrelate with the equation, the overall sum of each variable is categorized and then summed up. From the exercise conducted, the results conclude that the median $(\tilde{x})$ from the 50 samples of staff value is 4.94 while the mode $(M o)$ is N/A with $\mathrm{y}=0.0426 \mathrm{x}+4.0401$ and $\mathrm{R}^{2}=0.3154$. 


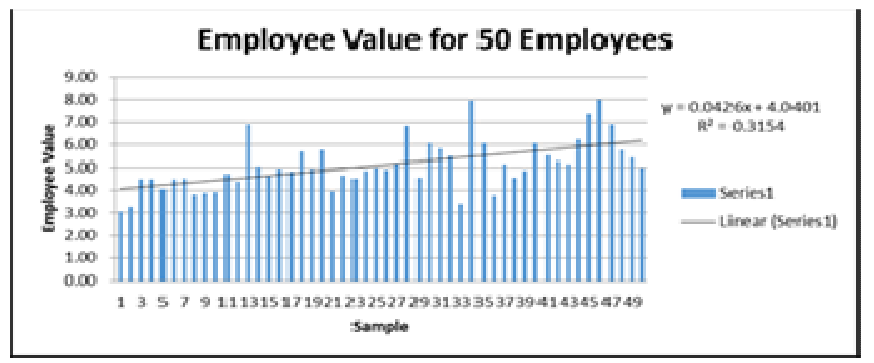

Fig. 5. Employee value from 50 samples

The mean $(\mu)$ of the 50 samples is 5.13 , while the standard deviation $\left(\sigma_{X}\right)$ is 1.10555888 (refer to Fig. 6).

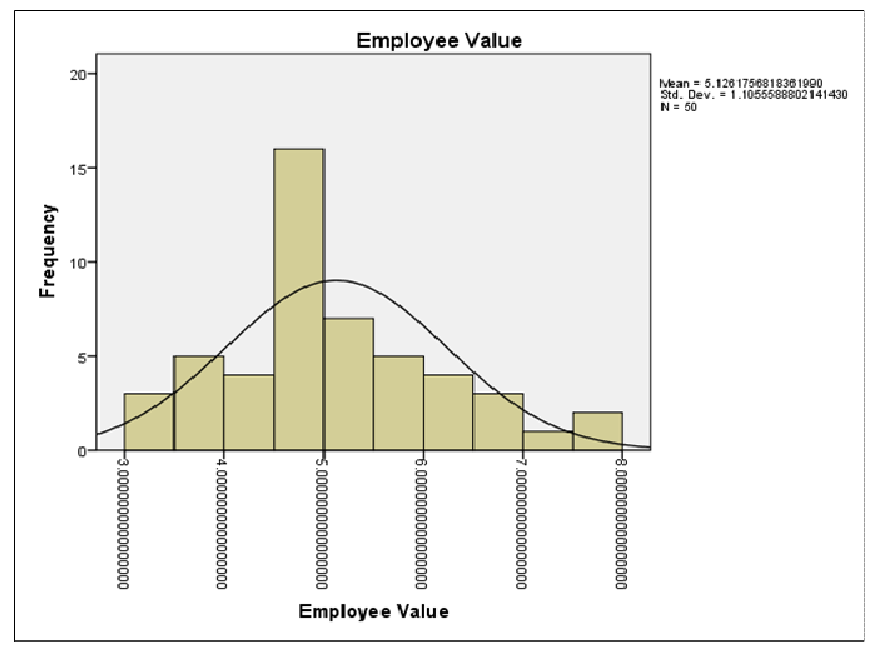

Fig. 6. Histogram

Then, the highest result from the samples was used in a $\mathrm{z}$ test to compare the mean result. The "a" variable was chosen for plotting the variance.
TABLE II

THE RESULT OF Z-TEST FOR SAMPLE 34 AND 46

\begin{tabular}{|l|l|l|}
\hline Sample & 46 & 34 \\
\hline & 79 & 77 \\
\hline Mean & 282.0833333 & 259.8333333 \\
\hline Known Variance & 19 & 22 \\
\hline Observations & 24 & 24 \\
\hline $\begin{array}{l}\text { Hypothesized Mean } \\
\text { Difference }\end{array}$ & & 0 \\
\hline $\mathrm{z}$ & & -17.02329824 \\
\hline $\mathrm{P}(\mathrm{Z}<=\mathrm{z})$ one-tail & & 0 \\
\hline $\mathrm{z}$ Critical one-tail & & 1.644853627 \\
\hline $\mathrm{P}(\mathrm{Z}<=\mathrm{z})$ two-tail & & 0 \\
\hline $\mathrm{z}$ Critical two-tail & & 1.959963985 \\
\hline
\end{tabular}

P-value (0.01) is smaller than alpha (0.05). Therefore, the null hypothesis stating that there is a significant difference in the means of each sample is not accepted. The result of this test proves that the equation can be used to measure employee value.

From the test, $\mathrm{P}(\mathrm{Z}<=\mathrm{z})$ two tail $(0)$ gives the likelihood that a value of the $\mathrm{z}$-Statistic $(-17)$ would be perceived as higher in entire value than the $\mathrm{z}$ Critical two-tail (1.96).

\section{A. Conceptual Model for Measuring the Value of an Employee}

For the final result of the study, a conceptual model was developed based on the result from the qualitative and quantitative methods performed. Each element collected from research materials was grouped according to its variables. For this study, all variables were matched with the IT field. The conceptual model is termed the Measurement Factor of Employee Value, and illustrated in Fig. 7.

\section{MEASUREMENT FACTOR OF EMPLOYEE VALUE}

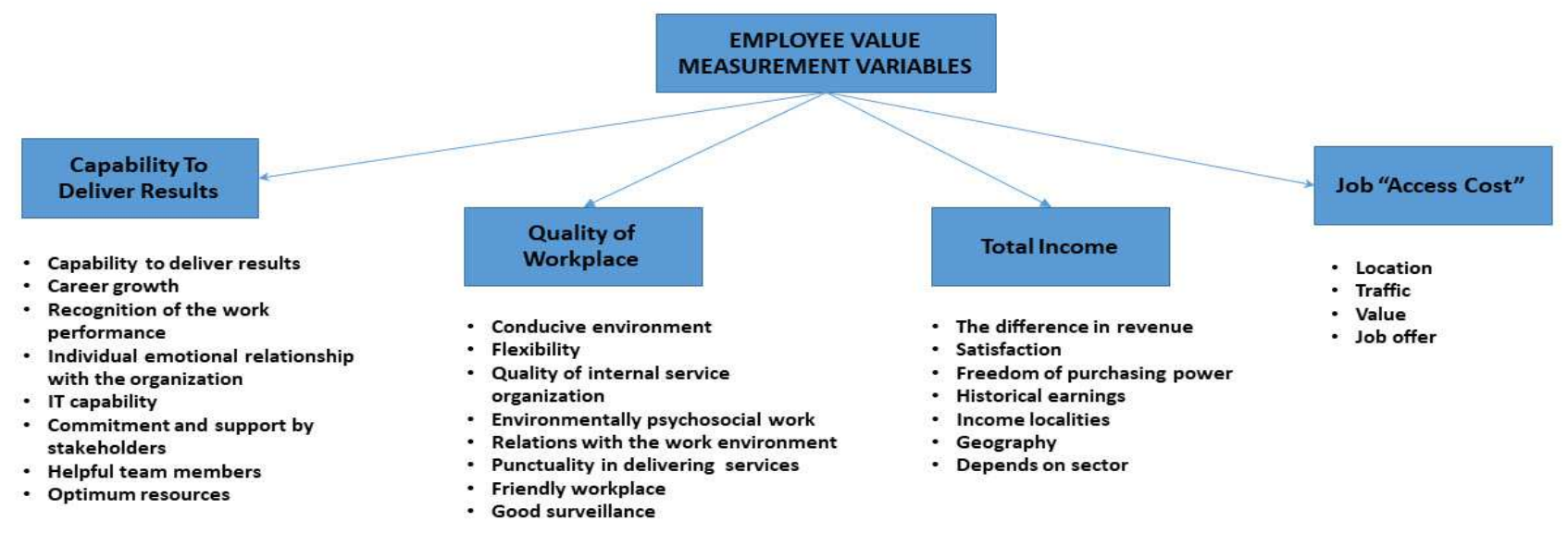

Employee Value Equation $=\frac{\text { Capability to Deliver Result }+ \text { Quality of Workplace }}{1 / \text { Total Income }+ \text { Job } " \text { Access Cost" }}$

Fig. 7. Conceptual Model 


\section{IV.CONCLUSION}

This study proves that the value of the employee can be measured by applying suitable elements in the equation variables. An organization can determine whether the employee is worth retaining or not based on this result. The organization can also specify which elements from the variables impact the result the most.

Based on the given equation, the distribution of the results from two samples using z-test is $99 \%$ for the confidence level. From the result, the values from sample 34 and 46 were the highest of all other samples. Also, both receive high salaries and have a low outflow in job access cost and the most important has the highest marks for the variable " $a$." This would be a pointer to the company to cope with employee retention as well as to set benchmarks in retaining their staff.

Besides that, a company would be able to improve and renew its organizational policies for elements of the factor that was rated low by the employee. For example, if the element relates to employee capabilities, the company might have to relook into their career advancement, and the training [36] required for the employee. If it was related to organizational surrounding [45], then, the organization should reconsider investing in long-term company sustainability.

Correspondingly, from the result, the organization can determine whether or not the retaining of their employees are based on their capabilities in delivering good results to the business or just only because the employee only wanted to preserve their employment based on other factors, i.e. workplace or job access cost. However other factors such as gender and age should also be considered because from the report, employees stayed longer in an organization as they got older [41] and this engagement may or may not benefit the company if the older employees retired and there was no replacement from competent youngsters. The workforce, specifically millennials, is keen to acquire more knowledge and skills instead of just receiving wages [46]. Therefore, their interests should be included as an incentive to retain them as part of the company, to drive the business.

The management of an organization can make decisions [47] based on the result of this value measurement-whether or not it is worth keeping the employee or vice versa. A suggestion to the company would be to design new people practices, foster a learning culture, and encourage employees, as well as adopt an agile mindset and promote a unique employee value proposition for talented employees [6].

Future work should consider several other elements such as evaluation scale, employee skills versus firm size, and push and pull factors.

The ratings of the value should be solidified, in order to give substantial meaning to the employer generally and to rate the staff accordingly; for example 0-3 (Incapable), 4-6 (Moderate), 7-10 (Capable), as this can determine whether the organization should retain the staff or not based on scale value. The value should interrelate with the overall result based on the total of the equation's result.

Subsequently, the factor for the variable " $a$ " has to tally with the staff's abilities, which match with the company, to avoid any discrepancy [48] and to retain the employee.
From the research, we can surmise that the variables in the equation lean more towards push factors (internal), which may result in dissatisfied workers moving away from the organization. In the meantime, IT staff turnover should also consider pull factors [19] (external) such as economic pattern, compensation, and offers from competitors, and so on. People may resign because of these factors. The push factor can be controlled by companies [49].

Hence, it is hoped that the findings of the study can help the IT sector overcome its retention issue and guide academicians in future studies in this field.

\section{ACKNOWLEDGMENT}

I like to convey my appreciation to the supervisor for the guidelines and support while writing this article. The experience taught me a lot. Also to other contributors for their guidance, consideration, and support in the completing this paper.

\section{REFERENCES}

[1] R. Roepke, R. Agarwal, and T. W. Ferratt, "Aligning the IT human resource with a business vision: The leadership initiative at $3 \mathrm{M}, " M I S$ Q. Manag. Inf. Syst., vol. 24, no. 2, pp. 327-352, 2000.

[2] R. S. DeLong, "Key strategies for retaining information technology professionals," ProQuest Diss. Theses, no. August 2015.

[3] G. Balamurugan and R. Abinaya, "A study on talent management strategies on employee retention in leading IT companies at Trichy," Rev. Res., vol. 5, no. 7, 2016.

[4] B. Kossivi, M. Xu, and B. Kalgora, "Study on determining factors of employee retention," Open J. Soc. Sci., vol. 4, pp. 261-268, 2016.

[5] M. S. M. Dhanabhakyam ., "The Mediating Role Of Emotional Exhaustion Through The Influence Of Organizational Justice On Employee Commitment And Employee Retention," Indian Streams Res. J., vol. 6, no. 2, 2016.

[6] ManpowerGroup, "2015 Talent Shortage Survey," 2015.

[7] K. M. White, "Better manage your Human Capital: Employees are Assets. You can enhance staff value through investment .," Nurs. Manage., 2006.

[8] J. Ambrosius, "Strategic Talent Management in Emerging Markets and Its Impact on Employee Retention: Evidence from Brazilian MNCs," Thunderbird International Business Review, 2016.

[9] B. Gill and A. B. Pidduck, "IT staffing and retention: A success story," in Proceedings of the ACM SIGCPR Conference, 2001, pp. 87-92.

[10] S. Omar, F. Noordin, Safiah Omar, Fauziah Noordin, S. Omar, and F. Noordin, "Career adaptability and intention to leave among ICT professionals: An exploratory study," Turkish Online J. Educ. Technol., vol. 12, no. 4, pp. 11-18, 2013.

[11] L. R. Arnold, "Strategies for Reducing High Turnover Among Information Technology Professionals," ProQuest Diss. Publ., 2005.

[12] S. J. Thomas, "Exploring Strategies for Retaining Information Technology Professionals: A Case Study," 2015.

[13] H. Meland, R. R. Waage, and M. K. Sein, "The other side of turnover: Managing IT personnel strategically," in SIGMIS CPR'05 Proceedings of the 2005 ACM SIGMIS CPR Conference, 2005, pp. 67-74.

[14] D. Dahiya and S. K. Mathew, "IT assets, IT infrastructure performance and IT capability: A framework for e-government," Transform. Gov. People, Process Policy IT, vol. 10, no. 3, 2016.

[15] U. Hana and L. Lucie, "Staff Turnover as a Possible Threat to Knowledge Loss," no. 3, 2011.

[16] S. Jothibasu, "A Study On The Employee Turnover Intention In Information Technology Industry Of Tamilnadu," Golden Res. thoughts, vol. 5, no. 10, 2016.

[17] Josh Bersin, "Employee Retention Now a Big Issue: Why the Tide has Turned," Bersin by Deloitte/ LinkedIn, 2013. [Online]. Available: https://www.linkedin.com/pulse/20130816200159-131079employee-retention-now-a-big-issue-why-the-tide-has-turned.

[18] T. Alina, "One Downside of an Up Economy : Employee Turnover," New York Times, vol. 401, p. 6, 2015.

[19] Nur Atiqah Abdullah, Norsiah Aminudin, Ahmad Khairi Ahmad 
Domil, and Khairul Akmaliah Adham, "Faktor pengekalan pekerja dalam firma IT di Malaysia," J. Teknol. Mklm. Multimedia., vol. 9, pp. 15-30, 2010.

[20] P. V. L. Raju, "Creating business value through people," Int. J. Learn. Intellect. Cap., vol. 3, no. 4, pp. 357-366, 2006.

[21] J. Heskett, E. Sasser, and L. Schlesinger, The Value Profit Chain: Treat Employees Like Customers and Customers Like Employees. New York, NY: The Free Press, 2003.

[22] S. Sudirman and Z. M. Yusof, "Public Sector ICT Strategic Planning: Framework Of Monitoring And Evaluating Process," J. Teknol. Mklm. Multimedia. Asia-Pasifik, vol. 6, no. 1, pp. 85-99, 2017.

[23] Z. S. Byrne, J. M. Peters, and J. W. Weston, "The struggle with employee engagement: Measures and construct clarification using five samples," J. Appl. Psychol., vol. 101, no. 5, pp. 1-27, 2016.

[24] R. Byte, "IT Employee Retention : It is Not All About the Money," 2008 .

[25] R. Brown, "Employee value proposition," Beac. Manag. Rev., pp. 29-36, 2012.

[26] J. L. Heskett, T. O. Jones, G. W. Loveman, W. E. Sasser, and L. A. Schlesinger, "Putting the service-profit chain to work," Harv. Bus. Rev., vol. 86, no. 7-8, 2008

[27] Pawar Avinash and Charak Kuldip S, "Sustaining employee value propositions: Linkages of employer branding and employee attraction," Rev. Res., vol. 5, no. 4, pp. 1-14, 2016.

[28] Nora Shafinaz Saedun and Ibrahim Mohamed, "Measuring employee value of IT staff in the banking sector through value profit chain variables," in 2017 6th International Conference on Electrical Engineering and Informatics (ICEEI), 2017, pp. 1-6.

[29] P. M. Carrig, Ken and Wright, "Building Profit through Building People: Making your Workforce the Strongest Link in the Valueprofit Chain," Soc. Hum. Resour. Manag., 2006.

[30] H.-C. Chae, "The impact of IT capability on employee capability, customer value, customer satisfaction, and business performance," ProQuest Diss. Theses, vol. Ph.D., 2009.

[31] J. L. Heskett, T. O. Jones, G. W. Loveman, W. E. Sasser, and L. A. Schlesinger, "Putting the Service Profit-Chain to Work," Harvard Business Review, vol. 72. pp. 164-174, 1994.

[32] C. G. Chi and D. Gursoy, "Employee satisfaction, customer satisfaction, and financial performance: An empirical examination," Int. J. Hosp. Manag., vol. 28, no. 2, pp. 245-253, 2009.

[33] Rhett H. Walker, Lester W. Johnson, and Sean Leonard, "Rethinking the conceptualization of customer value and service quality within the service-profit chain," Emerald Manag. Rev., 2014.

[34] J. G. Maxham, R. G. Netemeyer, and D. R. Lichtenstein, "The Retail Value Chain: Linking Employee Perceptions to Employee Performance, Customer Evaluations, and Store Performance," Mark. Sci., vol. 27, no. 2, pp. 147-167, 2008.

[35] M. R. Gasta, K. Davis, and E. D. Chairperson, "Driving Employee
Engagement Through Greater Purpose," 2016.

[36] E. Hoekstra, J. W. G. Major, S. K. Drake, L. H. Ebbers, S. A Freeman, and E. J. Mullen, "An exploration of the value profit chain for training transfer: A study of the relationship of workplace transfer climate to business goals and objectives in one firm," ProQuest Diss. Publ., no. UMI Number: 3085916, 2003.

[37] C. Lovelock and J. Wirtz, Services Marketing: People, Technology, Strategy, no. February. Prentice Hall, 2001.

[38] G. Ray, W. A. Muhanna, and J. B. Barney, "Information Technology and the Performance of the Customer Service Process: A ResourceBased Analysis," MIS Q., vol. 29, no. 4, pp. 625-652, 2005.

[39] D. Hoxsey, "Are happy employees healthy employees? Researching the effects of employee engagement on absenteeism," Can. Public Adm., vol. 53, no. 4, pp. 551-571, 2010.

[40] H. F. Rosenbluth and D. M. Peters, "The Customer Comes Second," 1992.

[41] F. F. Reichheld and T. A. Teal, "Loyalty Effect: The Hidden Force Behind Growth, Profits, and Lasting Value," Harvard Bus. Sch. Press Books, vol. 10, no. 1, p. 1, 2001.

[42] L. H. Nishii and D. M. Mayer, "Paving the Path to Performance : Inclusive Leadership Reduces Turnover in Diverse Work Groups," CAHRS Res., 2010.

[43] Catalyst Research Center, "Inclusive Leadership: The View From Six Countries," 2014.

[44] V. P. Pejvak and O. S. Cedergren, "A Study of How ICT Capabilities Can Influence Dynamic Capabilities," J. Enterp. Inf. Manag., vol. 29, no. 2, pp. 179-201, 2016.

[45] S. Hetzner, H. Heid, and H. Gruber, "Using workplace changes as learning opportunities: Antecedents to reflection in professional work," J. Work. Learn., vol. 27, no. 1, pp. 34-50, 2015.

[46] S. Frenking and S. Frenking, "Feel Good Management as a valuable tool to shape workplace culture and drive employee happiness.," Strategy. HR Rev., vol. 15, no. 1, pp. 14-19, 2016.

[47] M. Jalalkamali, A. J. Ali, S. S. Hyun, and D. Nikbin, "Management Decision Relationships between work values, communication satisfaction, and employee job performance: The case of international joint ventures in Iran," Emerald Manag. Rev., 2016.

[48] N. M. H. N. A. R. Nur Atiqah Abdullah, Ahmad Khairy Ahmad Domil, "Permintaan Firma Terhadap Industri Tenaga Kerja Teknologi Maklumat dan Komunikasi di Malaysia," J. Teknol. Mklm. Multimedia., vol. 3, pp. 71-87, 2006.

[49] Z. Fakhr, M. S. Ahmad, K. Zaman, B. Studies, Z. Fakhr, M. S. Ahmad, K. Zaman, B. Studies, Z. Fakhr, M. S. Ahmad, B. Studies, Z. Fakhr, M. S. Ahmad, K. Zaman, B. Studies, Z. Fakhr, M. S. Ahmad, K. Zaman, B. Studies, Z. Fakhr, M. S. Ahmad, and K. Zaman, "Measuring Push, Pull and Personal Factors Affecting Turnover Intention: A Case of University Teachers in Pakistan," Rev. Econ. Bus. Stud., vol. 3, no. 1, 2010. 